\begin{tabular}{r}
\hline \hline \\
$011 / 016(497.11)$ \\
$02(091)(497.11)$ \\
$930.85(=163.41)$ \\
https://doi.org/10.18485/msc_saopstenja.2018.48.1.ch3
\end{tabular}

Александра Б. ВРАНЕШ* Универзитет у Београду Филолошки факултет
Оригинални научни рад

Примљен: 02. 12. 2018.

Прихваћен: 03. 12. 2018.

\title{
БИБЛИОГРАФИЈА И БИБЛИОТЕКЕ У ФУНКЦИЈИ НАСТАВЕ СРПСКОГ ЈЕЗИКА У ИНОСТРАНСТВУ
}

\author{
Библиографија
}

Устаничке године с почетка 19. века (1804-1815) утопиле су се у двадесетпетогодишње преговоре, преко Хатишерифа $(1829,1830,1833)$ и Бера$m a(1830)$ окончане територијалним уступцима Турака и настанком вазалне Кнежевине Србије. Једном збацивши власт турских силника и стекавши самоуправу, Срби нису били спремни да трпе самовољу и аутократски режим кнеза Милоша Обреновића. Отуда су четрдесете године испуњене бунама против самовољног владара и изгласавањем Устава, донетог ван знања Русије и Турске, а у време када га ни оне саме нису имале. Слободоумност и западњачке навике уставописца Димитрија Давидовића, који Србију покушава да примакне Западу, борећи се за штампарију и за новине, сучељени су „везирском” апсолутистичком Милошевом ставу. Након што је окончана династијска криза, уставобранитељи су довели на престо Александра Карађорђевића, руковођени жељом да се успостави правна регулатива, коју неће надјачати личност аутократе на власти, и да се крене путем културног напретка. Културни напредак није започет са династијом Карађорђевића, већ годинама раније, још у време Милоша Обреновића, када је Крагујевац пружио окриље првој штампарији, новинама, позоришту и гимназији. Са уставобранитељима култура и школство доживљавали су свој пуни замах.

\footnotetext{
*aleksandra.vranes@gmail.com

** Текст представља спој ауторкиних раније објављених текстова у књигама Библиографија и Од рукописа до библиотеке, чији су библиографски подаци наведени у литератури.
} 
Отворено русофилство с почетка 19. века уставобранитељи су потискивали усвајањем француских и енглеских идеја. Отварање око две стотине нових школа, организовање Лицеја (у Крагујевцу 1838, премештен у Београд 1842); Богословије, Војне (1850), и Земљоделске школе (1853); законско уобличавање њихове организације и друштвене улоге и значаја, допринело је како културној, тако и политичкој самосвојности Срба.

Док се смена књижевног језика и правописа у 18. веку дешавала без значајнијих ломова и отпора литерарних кругова, 19. век је окарактерисала борба између славеносербског језика писаног старим правописом и народног говора, који Вук узима за основицу новог књижевног језика и правописа. Свестан тешкоће описмењавања маса, у ситуацији када „ни у сто села није било свуда једне школе”, а при том су језик и правопис били страни поимању обичног човека, сем неколицине свештеника, учитеља и књижевника, Вук Караџић је започео борбу против русификације српске културе залагањем за херцеговачки дијалекат, као основу књижевног језика, а потом за наддијалекатски књижевни језик. У његовим настојањима у почетку га подржавају и српски грађани у Аустрији, али повезивање новог језика и правописа са настојањима представника Илирског покрета, који код њих нису били омиљени, сужавало је круг Вукових присталица. Из борби са представницима Матице српске (Ђорђе Магарашевић, Јован Хаџић) и Друштва српске словесности (Јован Стерија Поповић), од 1832, када је његов правопис забрањен, до 1859, када је за приватна, то јест 1860. за државна издања, забрана скинута, Вук је изишао као победник чије су одане присталице били Ђура Даничић, Петар Петровић Његош, Бранко Радичевић, па чак и међу немачким интелектуалцима Гете, Грим, Ранке, Пирх, Фатер. Од 1868. године, када је коначно укинута забрана на коришћење Вуковог правописа, чак и у школским уџбеницима, „дефинитивно се гаси стара, клерикално-гражданска, а овладава нова, грађанско-демократска епоха у српској култури."

Увидевши да се личним покушајима не може знатније допринети „промицању просвете и културе”, српски народ је покретао „корисна разна удружења", међу којима је прва, још у Пешти 1826. године, основана Матица српска као „фонд за издавање Летописа и других полезних књига”. ${ }^{2}$ Петнаестак година након оснивања Матице српске, а две после абдикације кнеза Милоша (1839), током 1841, за време владе кнеза Михаила, предложено је од стране професора Јована Стерије Поповића, Атанасија Николића и вишег надзорника школа Димитрија Исаиловића, заснивање Србске наука академије, коју Попечитељство просвештенија, из скромности и обзирности, назива Дружство србске словесности. Руководећи се примером „други просвештени држава” предвиђено је да Друштво ради на „ображавању српскога језика и распрострањавању науке на српском језику”. ${ }^{3}$ Резултати тих истраживања редовно су објављивани у Гласнику Друштва србске словесности

\footnotetext{
${ }^{1}$ Исто, стр. 75.

${ }^{2}$ Хронологија Матице српске / Живан Милисавац. - У: Век и по Матице српске (додатак Политике), 5.12.1976, стр. 3 .

${ }^{3}$ Исто, стр. 161.
} 
(започет 1847), потом СУД-а, односно СКА ${ }^{4}$, његовим засебним издањима, као и онима која су по препоруци Друштва штампана о државном трошку. Пораст броја књижевних часописа и политичких листова с једне стране је доприносио културном и научном просперитету српског народа, с друге, пак, захуктавању борби унутар институција културе, као и између владајуће и опозиционих странака. Периодика осамдесетих и деведесетих година прошлог века већ самим својим насловима (Тежак, орган Српског пољопривредног друштва; Васпитач, чији је уредник Војислав Бакић, Рад уредника Пере Тодоровића) разоткривала је своју просветитељску мисију намењену ширим народним круговима, у коју се својим деловањем укључивало и Српско учено друштво.

Почетком деветнаестог века све већа пажња се поклањала образовању омладине. Све претходно наведене институције су описмењавање и школовање истицале као једну од својих програмских оријентација. Како се већина српских интелектуалаца школовала у Немачкој, то су широм отворена врата утицају немачких филозофа (Волфа, Еберхарда, Канта, Шелинга, Хегела, Хердера) и књижевника (Виланда, Шилера, Гетеа) на српске писце, о чему у књижевним делима сведочи и „наглашена [...] фолклорна и национално историјска компонента". повича, био далеко снажнији, ни сада потуно не узмиче. Па ипак, Србе далеко више привлачи борбеност Пољака и панславизам словачких идеолога, што нарочито оставља трага у стваралаштву угарских Срба, посебно међу омладином у Сегедину и Пожуну. Након револуционарне 1848. литерарно приближавање Европи је било још уочљивије, а шездесетих година се остваривао и обрнути процес: ширило се интересовање Европе за српску књижевност и културу. Тих година центар интелектуалног делања постаје Велика школа као „научни завод за вишу и стручну изображеност”, ${ }^{6}$ на којој предаје Ђура Даничић, чији су ђаци „творци књижевне климе у престоном граду у омладинско доба". мисао: „Свеучилишта су у културном животу оно, што су сунца на небеском своду; од њих долази светлост, која све греје и оживљава, ширећи се по свим висовима и долинама народнога живота; она покрећу на умни живот у народу, а где њих нема, ту поступно настаје мрак, који све уништава". И поред свести о његовој неопходности, Универзитет се у Србији, због политичких, друштвено-економских и националних разлога, оснива тек на почетку 20.

\footnotetext{
${ }^{4}$ Недоумица, честа у српској историји, о очувању континуитета, или потпуном раскиду са свиме што је претходило, поновила се и при утемељењу Српске краљевске академије од стране Милана Обреновића 1886. године, сучељене са постојањем и паралелним радом Српског ученог друштва све до 1892, када су се установе контролисано спојиле у једну. Успон Академије прекинули су балкански и Први светски рат (1912-1918), за којима је следило неколико година затишја (1918-1924). У четвртој деценији 20. века, када је Академија обележила и педесетогодишњицу свога настанка (1936), била је сасвим очевидна неопходност и драгоценост њеног претходног рада, као и научни углед који је стекла у земљи и свету.

${ }^{5}$ Романтизам : друга књига / Миодраг Поповић, Београд : Нолит, 1975, стр. 23.

${ }^{6}$ Зборник закона и уредаба о Лицеју, Великој школи и Универзитету у Београду, Београд, стр. 39.

${ }^{7}$ Романтизам : трећа књига / Миодраг Поповић, Београд : Нолит, 1975, стр. 241.
} 
века (1905), али је од тада „својом улогом у просвећивању доприносио и јачању државне независности". ${ }^{8}$

Обиље историјских и културних збивања остављало је трага и у српској штампи 19. века, која је, према Скерлићу, била „израз духовних струја” и пружала „нешто више но дневне новости и обичну забаву”. ${ }^{9}$ И сам Скерлић подсећао је на речи једног од зачетника српске журналистике Димитрија Фрушића да је она „прво, најлакше, најисходније средство за побудити к читању књига, размишљавању и напретку у цивилизацији и литератури". Покретање српских гласила, без обзира да ли је било у иностранству или у самој Србији, узроковало је и јачало духовно средиште српског живља. То је и разлог што су отпори државне власти отежавали покретање српских новина, а својим непрекидним упливом у политику уређивања и карактер објављених текстова, и њихово трајање.

У периоду када је Европа имала већ стогодишњу традицију објављивања дневних листова, Срби, и Јужни Словени уопште, добили су тек свој први часопис, Орфелинов Славъно-сербскій магазинъ и то „четири године пошто је престао да излази први руски часопис". ${ }^{10}$ Кратког даха, наговестио је не тако скоре покушаје писаца и штампара да установе периодику „на корист” српском народу. Након безуспешних напора Емануила Јанковића (од 1790, када је штампарију набављену у Лајпцигу пренео у Нови Сад, до смрти 1792) рађају се прве српске новине „десет година после Мађара, три месеца после Грка, седам година пре Словенаца и знатно пре Хрвата", ${ }^{11}$ што потврђује да су Срби били на „нивоу савремених културних народа Европе”. Биле су то Сербскїа новины повседневныл браће Маркидес Пуљо, које су, по Скерлићу, „имале безбојан, безличан и чисто информативан карактер”, будући утолико „српски лист што су се тако звале и што су штампане на ондашњем језику српске књижевности”. ${ }^{12}$ „Оптерећене слабостима: почетништва, неискуства, недовољне културне развијености, духовне и политичке скучености апсолутистичког и реакционарног система, прве српске новине значајне су највише стога што су Срби њима закорачили у једну нову, дотад непознату област јавног живота, у којој ће тек више деценија касније сасвим стасати и постићи запажене резултате." ${ }^{13}$ Српске листове тога времена притискали су с једне стране цензура, која је њихове вести чинила незанимљивим, с друге, пак, стране, незаинтересованост српског живља за овакав начин обавештавања. Битисање српских листова није било посебност само 18. века. И у првим деценијама 19. века ретке су биле периодичне публикације

\footnotetext{
${ }^{8}$ Органи управљања на Универзитету : 1905-1914 / Дубравка Стојановић. - У : Универзитет у Београду : 1838-1988, Београд, 1988, стр. 63.

${ }^{9}$ Историјски преглед српске штампе : 1791-1911 / Јован Скерлић. - Београд : Српско новинарско удружење, 1911, стр. 5.

${ }^{10}$ Српске књиге и српски писци 18. века / Лазар Чурчић. - Нови Сад : Књижевна заједница, 1988, стр. 184.

${ }^{11}$ Исто, стр. 184.

${ }^{12}$ Историјски преглед српске штампе : 1791-1911 / Јован Скерлић. - Београд : Српско новинарско удружење, 1911, стр. 5.

${ }^{13}$ Историја српске штампе у Угарској : 1791-1914 / Василије Ђ. Крестић. - Нови Сад : Матица српска, 1980, стр. 19.
} 
које су успевале да се дуже одрже. Новине С(е)рбске изъ ирарствујущчегъ града Віенне (1813-1822) као политички лист који је свесрдно пружио окриље књижевним и економским вестима „заснов” су Србским Новинама покренутим у Србији од стране истог уредника Димитрија Давидовића 1834. године. Стичући привилегије званичног листа штампаног у Државној штампарији, Србске новине, хваљене и оспораване, биле су најтрајнији периодикум са најширом публиком, те су постојањем, како својим, тако и свог књижевног додатка Подунавке, надомештали празнине, које је проузроковало гашење других часописа у матици.

У сталној борби за што већим бројем претплатника, који радије ишчитавају политичке од литерарних листова, уредници су током друге половине 19. века тежили да објасне и себи и „публикуму” зашто се многи мањи листови и часописи гасе и пре него што су обликовали своју физиономију. „Опште стање умно, политичко, економно, у српскога народа, не може да да ни публику која би тражила и ценила књижевне производе ни много књижевника који би у самој ствари били светли учитељи свога народа." ${ }^{14}$ Узроке спором напредовању књижевности појединци су налазили у чињеници да у Србији „нема великих вароши”. Стојан Новаковић, међутим, упозорио их је да у Аустрији има великих вароши, али ни у њој књижевност боље не напредује. Прави ,узрок нашој незгоди у продавању и протурању књига у томе је што нема књижевне публике у правом смислу. Нема много људи који би куповали књиге не да потпомажу писца, не да учине родољубну дужност него рад потребе, из унутрашњег покрета свог.” Да је чак књижевна публика и оформљена, чему школа треба да пружи знатан допринос, недостајао би за достизање циља „бољи обрт производа књижевних”.

Непризнавање националне индивидуалности српском народу крајем 18. и почетком 19. века у Угарској, у званичним документима, чак, понижавајуће називаном „неунијати грчког ритуала” било је само показатељ отвореног неслагања мађарске власти са пружањем било каквих слобода и права овој националној мањини. Културни развој Срба у Пешти је изазивао огромно подозрење и противљење, док је у Бечу, нешто мудрије, дочекиван са опрезом, уз стални надзор, али са свешћу о његовој неопходности и неминовности. Подунавски Срби су државним границама били раздвојени од своје матице, али својим духовним стремљењима, културним напорима и политичким покушајима ипак нераскидиво везани за њу. Отежавање живота, несигурност и страх проузроковани бруталним прогонима мађарских власти зауставили су дотадашње лучоноше, угарске Србе, на путу културног напретка. Чиљењем Пеште и Новог Сада као културних средишта, Србија и Београд преузимали су „духовну хегемонију у српском народу”. ${ }^{15}$ Ни Србија тада, као што је предочено, није била ушушкана колевка у којој су се могле безбрижно љуљушкати и расти књижевност и журналистика. Напротив, као што је већ

\footnotetext{
${ }^{14}$ Књижевни преглед / Андра Николић. - У: Отаџбина. - I, 1, 1-4 (1875), стр. 158.

${ }^{15}$ Историјски преглед српске штампе : 1791-1911 / Јован Скерлић. - Београд : Српско новинарско удружење, 1911, стр. 60.
} 
речено, била је растрзана супротстављеним интересима агилних политичких странака.

Значајан сегмент сваке, па и српске културе чини свакако и библиографија, наука која у историјској перспективи открива зачињање свести о важности сопственог народа кроз бележење података о његовој духовној баштини. Током 17. и 18. века у Европи се појављују библиографије анонимних и псеудоанонимних дела, инкунабула, часописа, појединих научних области, па чак и оне међународног карактера. Са развојем различитих типова библиографије, зависно од њихове садржине, значаја, степена обухвата грађе, временског распона, распореда, облика, територијалне и језичке припадности, начина обраде, врсте описа и врсте пописаних публикација, изнад свих се по своме значају за науку и културу једног народа уздигла национална библиографија. Без обзира на бројност и раширеност националне библиографије и у ранијим вековима, од петнаестог до осамнаестог, она свој пуни процват у Европи доживљава тек у 19. веку, на чијем је истеку по први пут и формално дефинисана. За разлику од библиографија у Европи, које се врло рано појављују у форми монографских пуликација, српске библиографије свој први искорак начиниле су у периодици.

Захарије Орфелин, покретач и уредник часописа Славеносербски магазин, не занемарује у њему библиографске вести. Назвавши их „Извъстия о ученых дълах", он постаје популаризатор науке, критичар писане речи и зачетник српске библиографије. Његов допринос нимало се не умањује констатацијом о руским узорима које многи биографи истичу. Павле Поповић, Мита Костић, и у новије време, у романсираној биографији о Орфелину, и Илија Мамузић, истакли су утицај часописа Sammlung Russicher Geschichte (1736-1765) и Ежемесечные сочинения и известия о учёных делах (17551764), које је уређивао Г. Ф. Милер. Тако и „предисловије” Славеносербском магазину представља прераду Милеровог предговора руском часопису Јежемесечнаја сочиненија. ${ }^{16}$ Упознавање његове библиотеке која се чува у Српској Патријаршији „показује да му је при руци било обимно, четворотомно дело једног од зачетника руске библиографије Хартмана Лудвига Бакмајстера Russische Bibliothek (1772-1774), о чему су писали Тихомир Остојић и Љубомир Котарчић. Откривши на којим пољима нас учена Европа надилази, Орфелин покушава не само да је достигне, већ и да јој се представи. Текућа библиографија коју он започиње, стога, због своје свестраности, може бити окарактерисана као „прва појава српске књижевне критике”17, „књижевна хроника"18, „преглед нових књига српских"19. Мада није издиференцирано ни као жанр, ни по припадности научној области, Известије о учених делах јесте исходиште библиографске мисли у Србији.

Почев од 1819. године, када је у Новинама српским у рубрици Смесице књижествене забележена прва књига на немачком језику коју је написао и у

\footnotetext{
${ }^{16}$ O izvorima Slaveno-serbskog magazina / P. Popović. - U: Prosvetni glasnik, 1755 (januar 1912), 1-12.

${ }^{17}$ Српска књижевност у 18. веку / Јован Скерлић, Београд, 1923, стр. 202.

${ }^{18}$ Исто, стр. 203.

${ }^{19}$ Историја српске књижевности / Јован Скерлић, Београд, 1953, стр. 61.
} 
Пешти објавио Јохан Чапловић ${ }^{20}$, постепено, али без прекида, расте интересовање за упознавање књига на страним језицима и страних књига које се односе на историју, књижевност и фолклор Срба. Исте године су Новине српске у покренутом Додатку забележиле и први библиографски податак о књизи (Руској библији) објављеној у иностранству, која се не односи на Србе, а у циљу поређења превода на српском и руском језику ${ }^{21}$. Упоредо са Смесииама книжественим Давидовић води и рубрику Кюижество српско, или, од 1819, Книжество славенско, на чијем почетку изражава велико задовољство што се на српском језику развија књижевност достојна хвале. Једна од описаних књига, апсолутна је новина, истакнута је као узор домаћим књижевницима. У питању су Историческо-критическе вједомости к повестници Пољског Књижества Јосифа Масимилијана Осолинског, на које би ваљало да се угледају домаћи историчари и библиографи како би се укључили у општа светска збивања. Да уредништво и у каснијим годинама редовно прати страну издавачку продукцију ишчитавајући написе о Србима, показује и цитирање одломака текстова из листова Kwěty и Pražske Nowiny, који се неблагонаклоно односе према Србским народним новинама и Подунавичи.

Изразити славенофил, Георгије Магарашевић је у Летопису сербском као први циљ својих истраживања поставио пописивање „славенских списатеља вообште", да би се већ у првој частици нашао преглед руске књижевности. Због сужавања појма српска библиографија, под којим нису подразумевали библиографије српских аутора о страним књижевностима, савремени теоретичари библиографије, у ретким прегледима њеног развоја, изостављали су неправедно овај део Магарашевићевог рада. На тај начин лишили су нас још једног сазнања: Магарашевић се није устручавао да укаже на изворе својих сазнања - напротив, његове напомене уз текст сведоче о познавању стране библиографске теорије и праксе.”22 У руској библиографији, осим тога, Магарашевић по први пут грађу не распоређује уобичајено хронолошки, или алфабетски, већ, према, условно речено, књижевним жанровима, на ауторе који су се одликовали у „лирическој и повествователној поезији за времена Александрова”, док остале групе чине: „прозаици, класически автора преводитељи, воени писатељи”23. У другој и трећој „частици” за 1825. Магарашевић наставља и преглед руске литературе, али је подела нешто разуђенија, па су обухваћени и аутори славни „у драматическој поезији”24. Најдоследнији и најпотпунији опис је у првом делу где су пописани „најстарији писмени славенски памјатници", пре свега руски, у хронолошком редоследу од $O \mathrm{~cm}$ ромировог јеванђеља 1057. до Лаурентиског кодекса $1377^{25}$. У осталим по-

${ }^{20}$ Новине сербске, 23 (19.3.1819), стр. 181-182. - Опис Чапловићеве књиге гласи: „Slavonien und zum Theil Croatien, am Beytrag zur Volker und Lamderkande. Theils aus eigener Ansicht und Erfahrung (1809-1812); theils auch aus spateren zuverlasigen Mittheilungen der Jusassen. Von Johann von Csaplovits. Pesth 1819, in Hartlebens Verlag".

${ }^{21}$ Исто, 68 (26.8.1819), стр. 517-520.

${ }^{22}$ Исто, стр. 156.

${ }^{23}$ Исто, стр. 156.

${ }^{24}$ Исто, част 2 и 3, стр. 104-105.

${ }^{25}$ Исто, стр. 85-88. 
глављима формулације су често уопштене и недоречене. Уз име аутора стоји: „Писао је многе комедије и трагедије”26. Новина и необичност коју је он, користећи страна искуства, унео у српску библиографију управо је у другачијем приступу систематизацији грађе, а не у обухвату библиографске јединице ${ }^{27}$. У наредном броју Летописа Магарашевић у Смесицама представља часопис који је 1823. године у Санкт Петербургу покренуо Петар Кепен под насловом Библиографическіе листы, које су: „главное назначеније сих листов состоит в том, что би сообштат полнија заглавија нових книг, на разних јазиках в Росији издаваемих и предлагат краткое изложеније их содержаније.” Самим тим што је нашао за потребно да извести о овој књизи Магарашевић је показао да је био свестан њеног значаја за славенску културу. Стога је и одлучио: „Ми ћемо нашима читатељима у будуштима частицама Сербске Летописа из ови Библиографическе листи известија, која се нарочито Сербске Литературе више тицала буду, сообштавати." 28 И, заиста, у четвртој „частици” за годину 1826. под бројем осам из Библиографских листова Кепенових Магарашевић преноси белешке о Сербском летопису, ${ }^{29}$ док у броју пет за исту годину поред библиографског записа о књизи Јосифа Добровског, Кирилл и Мефодий словенские первоучители. Историческо-исследование даје и објашњење где се налази код Кепена. Истичући другог библиографа, Петра Кепена, као ауторитет, и поткрепљујући своје белешке изводима из његовог дела, Магарашевић се више приближио ауторима друге половине 19. века. Прве потписане „смесице” у Летопису сачинио је Павле Стаматовић, набрајајући у другој „частици” за 1831. годину нове књиге у Русији, штампане највише у Санкт Петербургу и Москви. Одредница и даље није издвојена, али се као први податак у већини јединица налази наслов. Уколико је на првом месту име аутора, оно је у посесивном генитиву, и у ствари је саставни део наслова. Како је својим описима обухватао и руска издања, оправдано је претпоставити да је познавао и обимно библиографско дело Василија Сопикова, објављено 1813-1814. године, на које се често у своме часопису позивао Петар Кепен.

\footnotetext{
${ }^{26}$ Исто, стр. 105.

${ }^{27}$ Јер, његов опис не само да не садржи увек исте податке, већ их и не распоређује увек на исти начин. Доследан је у томе да прво наводи аутора, а затим сва његова дела, издвајајући тако одредницу, која је код ранијих библиографа занемарена. Уз име аутора бележи повремено годину рођења и смрти, или податке о занимању, уносећи тако биографске елементе ради којих овај преглед има одлике биобиблиографије. Наслов дела, који код свих библиографа тога времена представља основни, често и једини, појам за идентификацију књиге, овде је проширен и поднасловом, местом и годином издавања. Нажалост, Магарашевић у томе није доследан. За њега је далеко важније известити о постојању аутора (као што је случај у првој библиографској јединици о Арсић Евстахији), не чак ни књиге, него приуштити читаоцу комплетнији библиографски опис. Ни он, попут других библиографа, није имун од „скраћивања или проширивања наслова”. Писац је заступљен у библиографији и када није аутор монографије, већ прилога у часопису, али уместо потпуног библиографског податка пружена је само општа напомена: „Амвросиј Протасов (1. 1769) А Епкп. Казанскиј и Симб. Кав. - Његова поучителна слова још нису печатана совокупно; но нека у неким журналима.” Док је у Руској библиографији књиге (укупно 10) представљао по књижевним врстама, у Српској (која обухвата 37 аутора) одабрао је једноставнији алфабетски принцип, који није до краја применио.

${ }^{28}$ Сербски летопис за год. 1825 , стр. 143 /т.j.145/.

${ }^{29}$ Исто, 2 (1826), стр. 114
} 
На то упућује и наслов у одредници, који је основно обележје Сопиковљеве библиографије.

Јован Суботић као један од наредних уредника Летописа придаје значај упознавању сваког новог библиографског податка, макар га и преузимајући из радова осведочених културних посленика. Тако у првој свесци за 1845. започиње објављивање студије Преглед најзнатнији писмени споменика стари времена код Србаља и други Југославена од Павла Ј. Шафарика, коју је превео из Летописа бечких. ${ }^{30}$ Ова Суботићева напомена открива не само његову жељу да српски живаљ упозна са значајним културним споменицима, већ је посредно његово признање Шафарику као библиографу. Истовремено, она указује да су „смесице” за Суботића окриље библиографских вести. Од другог до четвртог броја за 1845 . годину у наставцима се доноси Шафариков чланак Рукописни споменици Србаља.

У Српском народном листу белешке о страној књизи су спорадичне. На томе послу огледају се Антониј Назаревич, који извештава о русинској ${ }^{31}$, Венцеслав Александер о пољској књижевности ${ }^{32}$, уредник Теодор Павловић о руском и чешко-словенском „Књижеству”з3, Шафарик о чешкој и П. А. Поповић о руској литератури. У своме писму из Прага П. Ј. Шафарик дели књиге „на библ. староческу, новоческу, инострани класика и домаћу, или популарну,” пописујући укупно шест наслова. Рубрику Смесиия П. А. Поповић попуњава записима о енглеској, француској и руској журналистици, чиме се приближава Павлу Стаматовићу. ${ }^{34}$

Од четрдесетих година 19. века чешћи су написи о славенском књижеству, који су и библиографски боље поткрепљени. Тако је у другој свесци Српског летописа за 1839. годину представљена најновија руска и пољска књижевност, при чему је она прва сагледана кроз новинарство и новелистику. Податак о издању који је за српске књиге тада редовно изостављан, ревносно је забележен за пољске књиге. Да ли стога што је тиме страна књига детаљније одређена, или стога што је грађа „из разни извора скупљена и уређена". 35

Упоредо са Књижеством сербским, мада у раздвојеним поглављима, Јован Суботић као посебну целину у Смесицама прати Книжество инославенско и Књиге у неславенским, језицима које о Славенма дејствују. ${ }^{36}$ Њему се током исте године придружује и Милош Поповић отварајући у Подунавции одељак Корешпонденција у броју 37 од 11. 9. 1843, да би га већ после трећег наставка, у бр. 42 од 16. 10. 1843, обуставио. Према предлошку Петра Доб-

30 „Ми ћемо овде, из истога све важније истог саставка точке у преводу саобштити и оне друге, које само као просто назначеније или регистер одкривени свога рода предмета изгледају, предложићемо у Смесииама С. Летописа, да се тако све, што се нас тиче, у нашим књигама наћи може”. Исто, 68, 1 (1845), стр. 29.

${ }^{31}$ Сербски народни лист, 4, 16 (18.4.1837), стр. 140.

${ }^{32}$ Исто, 4, 17 (28.4.1839), стр. 129-130.

${ }^{33}$ Исто, 4, 51 (21.12.1839), стр. 404.

${ }^{34}$ Исто, 4, 1-2 (7-14.1.1839), стр. 8 и 15.

${ }^{35}$ Сербски летопис, 13, 47 (1839), стр. 117-135.

${ }^{36}$ Исто, 17, 61 (2.2.1843), стр. 160-162 
ровског, уредника варшавско-словенског прегледа Денница, Поповић је овде представио 21 јединицу.

Антоније Хаџић само у једном броју објављује непотписан прилог Библиографични преглед у Аустрији излазећих славенских часописа. ${ }^{37} \mathrm{У}$ оквиру ове библиографије постоје засебне целине, које се односе на чешко-моравско-словачке (22 наслова), пољске (10), српско-хрватске (12) и словенске (4) часописе. Од српских часописа описана су текућа годишта Данице, Школског листа, Словенке, Српског летописа и Српског дневника, те има карактер годишње кумулативне текуће библиографије. Магарашевић је оставио трага и својим записима о југословенској, руској и чешкој књижевности. Ове библиографије нису оригинални радови, већ преводи, или прераде Александра Андрића из домаћих или страних часописа. Тако је Ческо књижество ${ }^{38}$ преузето из Ost und West за $1846 .{ }^{39}$

У Светозору, прилогу о књижевности, техници, науци и политици, објављује се Руска библиографија за год. 1856. Александра Смиридина, преузета из Спб. Вједомости, или се прештампавају обавештења из Прашких новина, Руског инвалида, Гласника Далматинског. ${ }^{40}$ У часописима који су неговали објављивање опште ретроспективне и текуће библиографије, или пак грађе за њих, нису биле реткост ни уже тематске библиографије. У Гласнику Друштва српске словесности запажа се библиографија Јована Ристића Србски, у изарској библиотеки паризкој налазећи се рукописи ${ }^{41}$.

Како у општој историји библиографије, тако и у библиографији српских рукописних и штампаних књига, најистакнутији су радови Стојана Новаковића. И то не само стога што су му записи бројни, свеобухватни и поуздани, већ и зато што је проблеме, које други нису ни примећивали, он теоретски расветљавао. Као евентуални узори ${ }^{42}$ нашем најбољем библиографу 19. века Стојану Новаковићу могу се истаћи немачки теоретичар библиотекарства и

\footnotetext{
${ }^{37}$ Исто, 100, 2 (1859), стр. 175-181.

38 Зимзелен, (1847), стр. 131-133.

${ }^{39}$ Обухвата 21 наслов управо издат и 1 који је у припреми. Име аутора наводио је на славеносрпском, а комплетан опис на језику оригинала. Непотпуност, непрецизност и произвољност библиографског описа доказ су да та дела Андрић није видео, а да извори на које се ослањао нису били лишени ових недостатака. Док је Српска библиографија била прецизно уазбучена, она која представља Руско књижество, преузета из Северне пчеле, нити је алфабетски, нити хронолошки уређена. Иако се насловом инсистира на томе да су побележена издања „из ове године”, међу 12 јединица изашлих 1848, као друга записана је једна из 1844 (Писма о Богосужени восточној католическој иркви. Сочинение А. Н. Мудравјева. 5, издање. Спб. 1844).

${ }^{40}$ Коректно наглашавање извора испод објављене вести показује да Андрићу није важан примат над другим новинама, већ што шире и објективније информисање. Како се објављене књижевне вести редовно односе на избор издања у текућој и допуне у претходној години, могло би се закључити да ови пописи имају одлике кумулативне текуће библиографије.

${ }^{41}$ Гласник Друштва српске словесности, 6 (1854), стр. 161-178. На међи каталога, јер описује део фонда Bibliothèque Imperiale, и библиографије, јер у поднаслову стоји „прилог за повестницу србске књижевности”, упознаје нас са осам споменика српског порекла од 13-15. века од седамнаест словенских, колико их се чува у Царској библиотеци.

${ }^{42} \mathrm{O}$ страној стручној литератури, која му је могла бити путоказ у изради библиографије, не сазнаје се директно из Новаковићевих записа, већ се само претпоставља на основу Каталога Српске народне библиотеке у Београду (1871), да су књиге, које су „трудом Стојана Новаковића” овде обухваћене, њему биле и добро познате.
} 
библиографије Јулијус Пецхолд (Julius Petzholdt), аутор три значајне књиге, Katechismus der Bibliothekenlehre (Лајпциг, 1856), Bibliotheca Bibliographica (Лајпциг, 1866), Heuer Anzeiger für Bibliographie und Bibliothekswissenschaft (Дрезден, 1857); дански научник Христијан Молбех (Christian Molbech) ca књигом Über Bibliothekswissenschaft (1829, у преводу на немачки 1833); руски библиографи Кепен, уредник часописа Библиографически листи, и Сопиков, састављач руске ретроспективне библиографије од почетака типографске делатности у Русији до 1813. године. У своме уводу у Onыт российской библиографий Сопиков је образложио коме је она намењена: „младим и љубопитљивим читаоцима, а највише онима који живе далеко од културних средишта и немају довољно могућности да себе опскрбе корисним књигама." 43 Ретка су и данас, а још више у том периоду, обухватна и лирски надахнута тумачења библиографије, какво је исписао Стојан Новаковић. Библиографија је за њега у односу на књижевност „статистика злијех и добријех дјела у разне периоде живота, статистика рађања и умирања, врлине и пријеступа, те је и она стекла свој попис душа, те и у њој бројеви и мјерење масе писанога и писалаца, публике и потребе њене дају оне исте дивне резултате које видимо у историји осталих грана људскога живота" ${ }^{44}$. Он верује да сваки „штампани ексемплар”, укључујући „књиге, зборнике, свеске или свешчице, новине или листиће”, без обзира на критичку процену, која не може да буде „руковођа”, треба да је обухваћен библиографијом, „на којој једино историк књижевности или образованости може изрицати своје признање или своју осуду овоме или оном времену културног или књижевног живота народног."45

Чешка књижевност, али само оним својим делом „колико се тиче Срба, Хрвата и Бугара" привукла је 1889. и пажњу Сретена А. Поповића ${ }^{46}$. Избор теме и начин расподеле грађе на чланке са и без имена писаца наводи на закључак да се Сретен А. Поповић угледао на свога непосредног претходника Едварда Јелинека. Прикупивши 110 ауторизованих и 101 адеспотно дело Поповић је начинио једну од опширнијих и поузданих библиографија из ове области. Његова заслуга је што је по први пут као засебне целине у библиографији разврстао „ориђинале” и „преводе”. За разлику од појединих савременика, који сопствене радове општим библиографијама нису обухва-

${ }^{43}$ Опыт российской библиографии, или Полный словарь сочинений и переводов, напечатанных на славенском и российском языках от начала заведения типографий, до 1813 года / Васил Сопиков. - Санкт Петербург : Типографија Императорског театра, 1815, књ. 3, стр. 5.

${ }^{44}$ Новаковић Стојан, нав. дело, стр. 5.

${ }^{45}$ Isto, str. 5-6. Сам је истицао Шафариково дело као „најглавнији извор” за осветљавање српске културне баштине, али је умео да увиди и пропусте и недоследности у описивању. „Тако, на прилику, Шафариково бележење формата није толико прецизно, да се већ по њему при ком одломку или посебном табаку какве старе књиге може одредити ако не од које је књиге, а оно од које је врсте издања.” Стојан Новаковић овај податак у Шафариковом опису уопштава, јер је, иначе, „формат у библиографији мало одређен и без утврђене за све мере, те га опредељује сваки по своме личном нахођењу", што смета при описивању савремене, а нарочито старе књиге. У своме библиографском извештају о зборницима за путнике Божидара Вуковића Новаковић подсећа да Шафарик користи термин осмина за сасвим мале књиге, док Вук Караџић прецизира да су некој књижици листови „тако мали, да би их из једнога садашњега табака средње величине могло изаћи $32 . "$

${ }^{46}$ Отаџбина, 7-21, 82 (1889), стр. 402-412. 
тали, Поповић је бележио и своја изворна и преведена дела. У жељи да боље представи књижевни опус превођеног аутора, на пример Лазе Лазаревића, или можда свој сопствени, Петровић је редовно у напомени расветљавао која су још дела истог писца када и где превођена. ${ }^{47}$

И уредништво Седмице посвећивало је нарочиту пажњу календарима, па је у рубрици Кюижевне вести скупно објављивало све њихове наслове за текућу годину, како оне штампане ћирилицом, тако и оне латиничне, све обједињене синтагмом „србски календари”. ${ }^{48}$ Поред вести о домаћим листовима, Седмица се није устезала да донесе сажетак из Руске библиографије за годину 1855, у којој је последње, двадесето, поглавље посвећено "периодичним изданијима". Систематизација 127 наслова (уз које се наводи само податак о годишњем броју свезака) на журнале и записнике и на новине, изнета je, вероватно, и као путоказ будућим библиографима. Далеко је важније да се на крају овог приказа критички указује на врлине (први покушај обухватне библиографије руског народа) и недостатке ове библиографије (непотпуност), што показује да је свест о неопходности и исцрпности библиографије код српских писаца већ увелико утемељена.

Док је средину 19. века карактерисало интересовање за немачку, француску и мађарску књижевност, а седамдесете и осамдесете године праћење словенских књижевности, на самом крају 19. века успостављена је равнотежа. Отуда у Зори, листу за забаву, поуку и књижевност, Кроника извештава упоредо о словенској (српској, хрватској и чешкој) и страним (немачкој и енглеској) књижевностима. Обједињујући вести о словенској и германској литератури, уредници су заборавили на основне постулате библиографског описивања: доследност, јединственост, прецизност и уређеност. ${ }^{49}$ Бранково коло доноси у наставцима текст Јарослава Кампера Годишиьияа чешке литеpamype $^{50}$, који је преведен из Das Magazin für Litteratur, a садржи податке о 53 књижевна дела. Током 1896. у рубрици Ковчежић више пута је извештавано о преводима из српске књижевности у страним гласилима, на пример, Лазаревићеве Школске иконе на чешки ${ }^{51}$, приповедака Лазе Лазаревића, П. Адамова, Симе Матавуља на словачки у листу Narodnie Noviny ${ }^{52}$, роману Ha-

${ }^{47}$ Исто, str. 407.

${ }^{48}$ Седмица, год. 7, 3 (19.1.1858), стр. 24; 4 (26.1.1858), стр. 32; О српским календарима постоји у рукописима Војислава М. Јовановића реферат Календари и алманаси као органи наше народне књижевности у 19. и 20. веку, који описује резултате рада Радмиле Ненин, асистента Института за књижевност од 13. децембра 1951. (стр. 2) и 3. марта 1953. (стр. 4), а поднет је Српској академији наука.

${ }^{49}$ Библиографија би се могла назвати кумулативно-текућом, али грађа није разврстана ни по хронолошком, ни по алфабетском принципу, а повремене напомене су крајње субјективне и различите дужине. Од броја 1 у 1899. до броја 1 у 1901. години Зора проширује свој круг сарадника, бележи за часописе и садржај, а уз то жели да на истом пољу окупи више водећих листова како би обрада текуће продукције, домаће и стране, текла организованије и свеобухватније. Отуда предлаже: „Бранково коло могло би узети на себе још и ту (кад је нама то немогуће) дабогме трудну дужност да региструје не само шта преводе политички српски листови, него и шта уопће доносе у својим подлисцима и одређеним ступцима за књижевност и просвјету."

${ }^{50}$ Бранково коло, 1, 14 (5-17.10.1895), стр. 436-440; 16 (19-31.10.1895).

${ }^{51}$ Бранково коло, 2, 15 (11-23.4.1896), стр. 478.

${ }^{52}$ Исто, 2, 28 (11-23.7.1896), стр. 891-893. 
зарени Јаше Томића на чешки и 32 јуначке и 19 женских народних песама на италијански (Canti Serbi tradotti da Giovanni Nikolić, 2. изд. 1896) ${ }^{53}$, шаљиве игре Мило за драго Драгомира Брзака на немачки ${ }^{54}$. Поједине од ових вести Бранково коло је преузимало из других часописа, али не некритички, као његови претходници, већ са поуком листу из кога је непотпуна објава пренета: „Добро је у тим приликама што тачније забележити где, када, па, ако је могуће, и ко је превео." 55

Током 19. века, резимирајмо, српска библиографија је настала, имајући у почетку карактеристике преписаног писменог задатка, и развила се до прегледног, анотираног и озбиљног монографског издања, у чијем је предговору успостављена и прва наша теорија библиографије. Такође, од узгредних напомена у смесицама до разгранатих свих типова библиографије прошло је стотинак година, али је у европским оквирима овај пут значајно дужи.

\section{Библиотеке}

Историја библиотека је део опште историје културе: развија се уз настанак писма и материјала за писање, стварање слоја писмених људи и писаних споменика. Српске библиотеке су зачете још пре осам векова у манастирима (Хиландар, Милешева, Матејча код Прилепа, Жича, Грачаница, Пећки манастир, Крушедол, Високи Дечани), богаћене у духовним светионицима средњег века при цркви (Црква светих апостола у Расу, 13. век; и при двору (владарске куће Немањића, деспота Бранковића), као штићена спремишта вредних књижних збирки, а њихово коришћење било је привилегија добро ситуираних владајућих слојева и врло учених људи. Крилатиле су у читалиштима и јавним библиотекама, захваљујући ентузијазму удружења грађана и националном просветитељском заносу 19. века, да би 20. век донео жељену демократизацију знања и нагло ширење акције оснивања јавних библиотека, нарочито после Другог светског рата.

У периоду од 1827. године (Возаровићево читалиште у Београду) до 1881. г. (Читаоница у Петровцу на Млави) основано је и радило 79 читалишта (често преименованих у читаонице, почев од 1866. и читаонице у Зајечару), као информационих, просветитељских, културолошких, чак националних политичких центара. У периоду до 1845. у Србији се, према истраживању Десанке Стаматовић, јављају сви типови библиотека (Библиотека Књажеске канцеларије 1815, Библиотека Вишег училишта србског 1817, библиотеке канцеларија нахијских старешина 1826. и 1829, Србска народна библиотека 1832, Шлезингерова „Музикална библиотека” 1835, Библиотека Богословије 1836, Библиотека Књажеско србске војне академије 1837, Библиотека Лицеја 1838, Позоришна библиотека 1841, Библиотека Српског ученог друштва

\footnotetext{
${ }^{53}$ Исто, 2,33 (15-27.8.1896), стр. 1051-1054.

${ }^{54}$ Исто, 2, 36 (5-17.9.1896), стр. 1150.

${ }^{55}$ Исто.
} 
1842). Замах у развоју јавног библиотекарства остварује се током педесетих и шездесетих година 20. века.

Библиотечко-информациони систем Србије обједињава 2476 библиотека, од којих су две националне (Народна библиотека Србије, Библиотека Матице српске), 27 окружних (обједињених функцијом матичности, која подразумева: вођење регистра библиотека, вођење каталога библиотечке грађе, пружање стручне помоћи библиотекама, надзор над стручним радом библиотека, старање о усавршавању кадрова за обављање библиотечке делатности, праћење и проучавање стања, потреба и услова рада у библиотечкој делатности и предлагање мера за унапређење библиотечке делатности и њихово спровођење), 1152 народне, са 958 стационираних и покретних огранака, 101 високошколском, 293 специјалне и 1175 школских.

Народна библиотека Србије у Београду (национална библиотека српског народа, основана је 1832, када је стекла право на обавезни примерак свих издања објављених на законом одређеној јој териорији). Потпуно је уништена у бомбардовању 6. априла 1941. године. После честих сеоба по углавном малим и неусловним просторима, Народна библиотека је 1973. године усељена у нову наменски зидану зграду, у којој је рад развила по одељењима, пратећи пут књиге по доласку у библиотеку, стављајући нарочити акценат на развијање каталошке, класификационе и библиографске праксе, конзерваторске лабораторије, заштите српске књиге у иностранству, као и учешћем у раду сесија ИФЛА организације. Данас обухвата 4.500 .000 библиотечких јединица, са 14 драгоцених легата и 25 самосталних збирки. Сарадња са преко 75 славистичких центара и више од 200 националних и универзитетских библиотека на пољу размене, позајмице, набавке материјала, организовања изложби, издавачке делатности не јењава још од седамдесетих година. Народна библиотека Србије интензивно ради на одржавању и ажурирању рефералних база података: ИНОЧАС (за иностране часописе), КООРДИ (за координирану набавку страних часописа и база података), ИНОМОН, ЈУКОНТ (базе апстраката на енглеском и српском језику), као и на припремању мултимедијалних публикација. У октобарским данима књиге Библиотека је покровитељ Београдских међународних сусрета писаца.

Библиотека Матице српске, основана 1826. године у Пешти, континуирани развој наставила је од 1864. године у Новом Саду; располаже фондом од 2700000 публикација и значајним библиотекама-целинама, а матична је за све високошколске библиотеке у Војводини. Реферални центар од 1985. године учествује у изради међународне базе података за пољопривреду АГРИС. Библиотека у едицији Трагови објављује стручне текстове својих радника, а редовно и компетентно издаје Годишњак Библиотеке Матице српске, Библиографију књига у Војводини и тромесечно информативно гласило Вести.

Народна и универзитетска библиотека „Иво Андрић” као своје почетке бележи Обласну народну библиотеку из 1944. године, а сада је информационо документациони центар Универзитета у Приштини са око 1.000 .000 библиотечких јединица, измештен ван свога матичног седишта. 
Народна и универзитетска библиотека Републике Српске зачета је као Јавна народна библиотека 1936; функције универзитетске библиотеке преузела је 1980, а националне 1999. године, након чега је и понела данашње име. Као национална, матична је за све библиотеке на простору Републике Српске (7 матичних народних, 48 јавних, 215 регистрованих школских библиотека); као јавна, матична је за библиотеке у регији Бањалуке (9 народних, 17 специјалних, 31 школска), а као универзитетска за све високошколске библиотеке у српском ентитету (15 факултетских у Бањалуци). Разуђеност њених функција утиче на њену организациону структуру, те се у библиотеци издвајају: Национална (ISBN/ISMN агенција Републике Српске, Библиографско-завичајно и археографско одељење), Универзитетска (Реферално одељење, Студијске читаонице, Стране читаонице, Одељење периодике) и Градска јединица (ИПО - за одрасле, Дечије одељење са читаоницом, Огранак Обилићево са читаоницом, Интернет клуб). Народна и универзитетска библиотека Републике Српске располаже фондом од 538.425 библиотечких јединица, од којих је 215.381 наслов монографских, 330 старих и ретких књига, магистарских и докторских радова 291, 3076 наслова серијских публикација у 323.044 свеске и легатом Душана Ђоновића од 4132 јединице. Поред класичног система лисних каталога Библиотека развија 11 база података: Корисници НУБРС, БИБЛИО, Дечија књига, Немачка књига, Франиуска кьига, Енглеска књига, Периодика, СІР Републике Српске, Легат Душана Ђоновића, Докторски, магистарски и спеиијалистички радови, Издавачи Републике Српске, Записи унесени из старог лисног каталога.

Универзитетска библиотека „Светозар Марковић” у Београду зачетке има у библиотеци Лицеја 1838. и Велике школе 1864 . године, а од 1926. године настањена је у згради подигнутој и средствима Карнегијеве фондације. Библиотека је општенаучна и садржи 1.400 .000 свезака из свих области људског знања, 26 самосталних личних библиотека и богату збирку докторских дисертација одбрањених на универзитетима у Србији.

Универзитетске библиотеке у Нишу и Крагујевцу употпуњују породицу високошколских библиотека.

Челне специјалне библиотеке у Србији су Библиотека Српске академије наука и уметности (основана 1842. године) у којој се, поред општег фонда од 1.200 .000 свезака, чува и биографска и библиографска документација о члановима Академије; Библиотека Српске патријаршије (зачета 1737, сељена од Сремских Карловаца, Сент Андреје, делом и Загреба, до Београда) са богатом збирком рукописних и старих штампаних књига; Централна библиотека Војске Југославије, која датира из 1862. године, када је радила при Министарству војном, а од 1947. године је самостална установа.

По етничком и лингвистичком критеријуму српске су и библиотеке које се налазе и ван територија Србије. Библиотека манастира Хиландара је најстарија српска библиотека (основана у 12. веку), која данас поседује 1150 рукописа, 383 хрисовуље, и повеље на пергаменту и папиру, 76 старих штампаних књига, 6 инкунабула, 4518 старих књига, преко 40.000 монографских и серијских публикација од 18. до 20. века. 
Народне библиотеке, којих у Србији има 167, нарочито негују своје завичајне фондове који представљају здраву основу за формирање националног фонда, јер су у њима сакупља грађа која је по етничком, лингвистичком, предметном, хронолошком, или географском принципу везана за територију завичаја.

Институција на чије је постојање и начин рада распад Југославије оставио немилог трага је Југословенски библиографски институт. Његови корени су на Филозофском факултету (1920), мада је основан под окриљем државе 1950. и током свога педесетогодишњег трајања (до 2003) објављивао је за целу Југославију текућу библиографију монографских, серијских публикација, прилога у самосталним публикацијама, рото штампе, владиних докумената у засебним серијама. Био је друштвено оправдан и сврсисходан као део комплекснијег библиотечког организма, какав више не постоји, те је његове функције, нарочито израду текуће библиографије, сарадњу у области ажурирања и дистрибуције Универзалне децималне класификације и активности везаних за категорије међународних стандардних бројева за различите врсте библиотечке грађе, преузела Народна библиотека Србије 2003. године.

\section{Филолошки факултет Универзитета у Београду}

Филолошки факултет Универзитета у Београду, видан и јединствен на образовној и научној мапи Србије, па и Европе, по бројности језика и дисциплина које се на њему изучавају, има различиту организацију библиотека у односу на све високошколске установе Универзитета у Београду. Свака катедра и семинар имају своју библиотеку, те на Филолошком факултету ради 17 библиотека (обликованих, углавном, према лингвистичком принципу), од којих је пет у оснивању. Оне представљају пуну подршку наставно-научном процесу везаном за области: српске књижевности и српског језика и јужнословенске компаратистике; српског језика са јужнословенским језицима и општом лингвистиком; славистике; романистике; румунског језика и књижевности; италијанског језика и књижевности; иберијских студија; енглеског језика и књижевности; германистике са скандинавистиком; албанског језика и књижевности; оријенталистике; опште књижевности са теоријом књижевности; библиотекарства и информатике; хунгарологије. Свака од поменутих библиотека набавља и чува литературу, обрађује је (инвентарише, каталогизује, класификује и по потреби аналитички представља), даје на коришћење и обавља све остале библиотечке послове (ревизије фондова, заштите библиотечке грађе, припремања изложби) потпуно самостално, уз координацију на пољу имплементације COBISS-a.

О богатству факултетских библиотека најбоље сведочи задовољство студената и научних радника, који скоро сву потребну литературу налазе у фондовима, могу да је користе код куће и у светлим читаоницама (са референсном збирком), отвореним 60 сати недељно. Формални обједињени по- 
казатељи нипошто не одсликавају богатство и разнородност фондова, али ваља констатовати да укупан фонд библиотека Филолошког факултета, по збиру, значају и вредности, укључујући и збирку ћирилских рукописних и штампаних књига и 14 поклон библиотека, укључује Филолошки факултет Универзитета у Београду међу најзначајније библиотечке центре у Србији. У библиотекама се израђују и библиографије истраживача, традиционално, а започет је и њихов електронски унос. Од 2004. године библиотеке Филолошког факултета су приступиле Узајамном виртуелном каталогу Србије (у програму COBISS).

Филолошки факултет Универзитета у Београду иницирао је бројне научне пројекте, у оквиру конкурсних позива Министарства просвете и Министарства културе, али и потпуно независно од њих. Убеђени да је дигитални облик валидан и вишеструко пожељан облик, чак и научне комуникације, започели смо на Факултету формирање сопствене дигиталне библиотеке. То је сада једна од најзначајнијих дигиталних библиотека академских књига (објављених факултетских издања) у Србији у слободном приступу: истакнутих периодичних публикација, едиције докторских дисертација одбрањених на Филолошком факултету, зборника радова са међународних научних конференција, монографских публикација, антологија, збирки, уџбеника. Потреба је и жеља Филолошког факултета да се нашој научној продукцији обезбеди пуна видљивост, промоција и доступност преко сајта Филолошког факултета. Сви дигитализовани садржаји су потпуно и унакрсно претраживи, како по ауторском, насловном, стручном, предметном, хронолошком критеријуму, тако и по свакој речи из текста, чиме се омогућавају разноврсна и широка лингвистичка, лингвостилистичка, књижевнотеоријска и књижевноисторијска истраживања. Корисницима Дигиталне библиотеке Филолошког факултета омогућено је претраживање на језику и писму оригиналног текста и равноправно коришћење ћирилице и латинице у унетим упитима.

У европским оквирима очекује се да се дигитализацијом обезбеди кључни механизам за коришћење јединственог европског наслеђа и за подршку културној разноликости, и ми смо у процесу стварања дигиталног оквира научног и културног наслеђа Србије.

Други део пројекта односи се на дигитализацију рукописних заоставштина истакнутих писаца: 1) аутора чије је рукописно наслеђе власништво Филолошког факултета (Иван В. Лалић и Александар Вучо); 2) аутора за чију је дигитализацију рукописног наслеђа Филолошки факултет потписао уговоре о сарадњи (Иво Андрић).

Предрагоцени пројекат дигитализације личног фонда Ива Андрића, истовремено је и прва фаза у реализацији пројекта припреме Целокупних дела Иве Андрића. Лични фонд Иве Андрића у власништву је Задужбине Иве Андрића, а чува се у Архиву САНУ. Ради тога је Факултет ступио у уговорни однос са обе истакнуте институције, јер смо, мислим на све три институције науке и високог образовања, више од 50 година након што је Андрић добио Нобелову награду, сматрали да је то наша научна и друштвена обавеза и национална одговорност и понос. 
Филолошки факултет је иницирао захтеван подухват припреме Целокупних дела Иве Андрића, што је озбиљан и одговоран чин националног, научног и академског чувања наше баштине у сврху развоја научних истраживања. На наше велико незадовољство, можемо скрушено да признамо да је мали број писаца у нашем народу чије је стваралаштво заокружено критичким издањем целокупних дела. Рад на реализацији пројекта критичког издања Целокупних дела Иве Андрића и библиограф и приређивач доживљавају као привилегију.

Филолошки факултет, у сарадњи са Задужбином „Иво Андрић”, Српском академијом наука и уметности, Андрићевим институтом, Народном библиотеком Србије, Институтом за књижевност и уметност, Универзитетском библиотеком „Светозар Марковић”, Филозофским факултетом у Новом Саду, Филозофским факултетом у Нишу и Филолошко-уметничким факултетом у Крагујевцу, први пут на овај начин посвећује пажњу целокупним делима Иве Андрића. До сада су одржана три припремна састанка уређивачког одбора Целокупних дела Иве Андрића, на којима је предлагано и одлучивано: да се на Филолошком факултету оснује Центар за текстолошка истраживања, што је у Статут и укључено; да прва фаза рада на Целокупним делима буде дигитализација Андрићевог Личног фонда, што не само да је испуњено, већ су у електронски облик стављени и сви материјали који припадају другим фондовима, а везани су за Андрића; да се обезбеди научни и друштвени легитимитет овом пројекту. Пројекат се одвија под покровитељством Председника Републике Србије. На седници Уређивачког одбора Целокупних дела Иве Андрића одржаној 18. јуна 2012. предложено је да се у пројекат укључи Емир Кустурица, који се придружио уз посредовање и подршку Министарства просвете, науке и технолошког развоја Републике Србије.

Дана 11. јула 2012. године Филолошки факултет Универзитета у Београду потписао је уговор о сарадњи са Задужбином Иве Андрића, као искључивим носиоцем ауторских права. Задужбина нам је уступила право да дигитализујемо Свеске Задужбине Иве Андрића, Каталог Личног фонда, чији су аутори Олга Мучалица и Анђелија Драгојловић и, надасве најважније, рукописну заоставштину Иве Андрића, сачувану у Архиву САНУ. Факултет се уговором и, наравно, својом академском чашћу, обавезао да своју дигиталну библиотеку, чији сегмент треба да буде дигитализована рукописна заоставштина Иве Андрића, учини бесплатно доступном корисницима Задужбине Иве Андрића. Истовремено, тачније 3. јула 2012. године, Филолошки факултет је, на предлог Архива САНУ, добио одобрење Извршног одбора САНУ да може приступити дигитализацији рукописне заоставштине Иве Андрића, уз поштовање посебних услова, какви су: рад техничког особља у просторима читаонице Архива САНУ, непрекидна стручна сарадња са архивистима у дефинисању атрибута којима се описује сваки документ, потпуна посвећеност послу и педантност обраде. Стална професионална ангажованост стручњака Архива САНУ Милета Савића, обезбедила је потпуну тачност и максималну информативност одредница.

Дигитализација Андрићевих рукописа обављена је према прописима који се односе на архивска документа у програму Spider.net, који је резултат 
рада стручњака фирме МФЦ „Микрокомерц” и већ је примењен за потребе Музеја Николе Тесле, Министарства за државну управу, Министарства за људска и мањинска права, Националне службе за запошљавање, Градске управе Града Београда, Београдских електрана, Рајфајзен банке, Термоелектране „Костолац” и бројних других установа.

Дигитализација грађе, у којима је и она која до сада није објављивана, драгоцена је за историјско, политичко и књижевно закључивање. У електронску форму стављени су и бројни Андрићеви текстови који културној јавности уопште нису познати. Укупан обим дигитализованих рукописа доступних у Архиву САНУ износи 118.100 докумената и они су претраживи по упитима: каталошки број, група докумената, подгрупа докумената, архивска кутија и опис документа, чиме се прати структура каталога личног фонда, која наравно у потпуности одговара организацији фонда у Архиву САНУ.

Употреба дигитализованог рукописног материјала одвија се уз дозволу Задужбине „Иво Андрић” и реализацију Филолошког факултета. Његова изврсност и јединственост чине га преко потребним нашој научној заједници. Пројекат дигитализовања рукописне заоставштине Иве Андрића значајан је као целина, али је такође, прва и огледна база рукописних докумената једног писца у Србији, а слична нам није позната ни у свету. По овом обрасцу се даље отвара пут за заштиту и дигитализовање других личних фондова наших писаца. Дигитализацијом Андриђеве рукописне заоставштине омогућили смо заштиту фонда, олакшан приступ драгоценим материјалима, већ подложним озбиљнијим оштећењима, посвећено научно истраживање и текстолошке анализе које нису ограничене радним временом Архива, заинтересованошћу другог корисника за исти документ, или нечитљивошћу рукописа, који се не може довољно увеличати како би био прочитан, као и пласман наше културне баштине и наше науке у електронском окружењу.

Целокупна дела Иве Андрића обезбедиће трајну одрживост и научну употребљивост педантног и посвећеног поступка дигитализације рукописа, а нашој културној и научној заједници темељно критичко издање, незаобилазно у свим будућим истраживањима и ишчитавањима.

Током 2018. године завршена је и дигитализација рукописа Ивана В. Лалића и Александра Вуча, за чије ће коришћење сагласност давати Филолошки факултет Универзитета у Београду.

\section{ЛИТЕРАТУРА}

Опыт российской библиографии, или Полный словарь сочинений и переводов, напечатанных на славенском и российском языках от начала заведения типографий, до 1813 года / Васил Сопиков. - Санкт Петербург : Типографија Императорског театра, 1815.

Српска књижевност у 18. веку / Јован Скерлић. - Београд, 1923. 
Српска библиографија XVIII века / Георгије Михаиловић. - Београд : Народна библиотека СР Србије, 1964 (Београд : Култура). - XXXIV, 383 стр. : илустр. ; 30 cm. - (Српска ретроспективна библиографија / Народна библиотека СР Србије)

История иностранной библиографии / К. Р. Симон. - Москва : Всесоюзная книжная палата, 1963. - 735 стр. ; $23 \mathrm{~cm}$.

Историја српске штампе у Угарској : 1791-1914 / Василије Ђ. Крестић. Нови Сад : Матица српска, 1980.

Српске књиге и српски писци 18. века / Лазар Чурчић. - Нови Сад : Књижевна заједница, 1988.

Библиографско дело Стојана Новаковића : одломак из студије / Душан Панковић. - Београд : Библиотекарско друштво Србије, [1995]. - Стр. 4-30 ; $24 \mathrm{~cm}$ П.о.: Библиотекар, бр. 1-2, 1994.

Основи библиографије / Вранеш, Александра. - Београд : НБС, 2001. - 201 стр. Bibliographic Sources : an Important Tool for Distance Learning / Vraneš, Aleksandra. - In: Proceeding at the International Conference held in Sofia at the University "Kliment Ohridski" Libraries, globalisation and Cooperation, November 3-5, 2004. - Sofia : University "Kliment Ohridski”, 2005. - p. $109-116$.

Српска библиографија данас : зборник радова / [главни и одговорни уредник Александра Вранеш]. - Нови Сад : Матица српска, 2008 (Нови Сад : Прометеј). -275 стр. ; $24 \mathrm{~cm}$.

Од рукописа до библиотеке : појмовник / Александра Вранеш, Љиљана Марковић. - Београд : Филолошки факултет, 2013.

Библиографија / Александра Вранеш. - Београд : Филолошки факултет, 2013.

Aleksandra B. Vraněs

BIBLIOGRAPHY AND LIBRARIES IN THE FUNCTION OF TEACHING SERBIAN

LANGUAGE

Summary

A lecture given to students of the Serbian language at Andrić Institute in Andrićgrad in September 2018 includes an overview of the development of the Serbian bibliography, especially through the presence of a foreign book and its translations, and Serbian libraries, including the libraries of the Faculty of Philology. 